\title{
Predictors of willingness to get a COVID-19 vaccine in the U.S
}

\author{
Bridget J. Kelly ${ }^{1 *}$, Brian G. Southwell1', Lauren A. McCormack', Carla M. Bann, Pia D. M. MacDonald ${ }^{1,2}$, \\ Alicia M. Frasier ${ }^{1}$, Christine A. Bevc ${ }^{1}$, Noel T. Brewer ${ }^{2}$ and Linda B. Squiers ${ }^{1}$
}

\begin{abstract}
Background: As COVID-19 vaccine distribution efforts continue, public health workers can strategize about vaccine promotion in an effort to increase willingness among those who may be hesitant.

Methods: In April 2020, we surveyed a national probability sample of 2279 U.S. adults using an online panel recruited through address-based sampling. Households received a computer and internet access if needed to participate in the panel. Participants were invited via e-mail and answered online survey questions about their willingness to get a novel coronavirus vaccine when one became available. The survey was completed in English and Spanish. We report weighted percentages.

Results: Most respondents were willing to get the vaccine for themselves (75\%) or their children (73\%). Notably, Black respondents were less willing than White respondents ( $47 \%$ vs. $79 \%, p<0.001$ ), while Hispanic respondents were more willing than White respondents ( $80 \%$ vs. $75 \%, p<0.003)$. Females were less likely than males ( $72 \%$ vs. $79 \%, p<0.001)$. Those without insurance were less willing than the insured ( $47 \% \mathrm{vs} .78 \%, p<0.001)$. Willingness to vaccinate was higher for those age 65 and older than for some younger age groups ( $85 \%$ for those 65 and older vs. $75 \%$ for those $50-64, p<0.017 ; 72 \%$ for those $35-49, p<0.002 ; 70 \%$ for those $25-34, p=$ NS and $75 \%$ for ages $18-24, p=N S)$, but other groups at increased risk because of underlying medical conditions or morbid obesity were not more willing to get vaccinated than their lower risk counterparts.
\end{abstract}

Conclusions: Most Americans were willing to get a COVID-19 vaccine, but several vulnerable populations reported low willingness. Public health efforts should address these gaps as national implementation efforts continue.

Keywords: COVID-19 vaccine, SARS-CoV-2 vaccine, Vaccine hesitancy, Public health communication

\section{Introduction}

As nations across the globe continue to distribute COVID-19 vaccinations to eligible individuals, some health officials argue that the time is fast approaching when issues with logistics and short supply will be replaced by the need to reach those who are more reluctant to vaccinate $[1,2]$. A global study found that $72 \%$ of people would take a Covid-19 vaccine if proven safe and

\footnotetext{
* Correspondence: bkelly@rti.org

${ }^{1}$ RTI International, Research Triangle Park, 701 13th St. NW, Ste. 750, Washington, DC 20005, USA

Full list of author information is available at the end of the article
}

effective, but willingness varied widely between nations [3]. Studies in Australia and Indonesia have found that willingness varies widely depending on the vaccine's effectiveness and that safety is a concern $[4,5]$.

Given the unique features of this particular virus-its highly contagious nature, high severity for certain groups, and the significant impact it has had on people's daily lives through social distancing and business closures-we sought to better understand the American public's willingness to get a COVID-19 vaccine. We also sought to characterize willingness among groups most at risk for severe COVID-19 (e.g., people age 65 or older,

(c) The Author(s). 2021, corrected publication 2021. Open Access This article is licensed under a Creative Commons Attribution 4.0 International License, which permits use, sharing, adaptation, distribution and reproduction in any medium or format, as long as you give appropriate credit to the original author(s) and the source, provide a link to the Creative Commons licence, and indicate if changes were made. The images or other third party material in this article are included in the article's Creative Commons licence, unless indicated otherwise in a credit line to the material. If material is not included in the article's Creative Commons licence and your intended use is not permitted by statutory regulation or exceeds the permitted use, you will need to obtain permission directly from the copyright holder. To view a copy of this licence, visit http://creativecommons.org/ licenses/by/4.0/. The Creative Commons Public Domain Dedication waiver (http://creativecommons.org/publicdomain/zero/1. 0/) applies to the data made available in this article, unless otherwise stated in a credit line to the data. 
those with specific underlying medical conditions, or with a body mass index (BMI) $>40$; and Black and Hispanic Americans) [6]. We examined these questions in a national survey of U.S. adults.

\section{Methods}

\section{Participants and procedures}

We surveyed U.S. households in April 2020 using a prerecruited, address-based web panel consisting of 55,000 adults. The panel is based on probability sampling covering both the online and offline populations in the United States. Households received a computer and internet access if needed to participate in the panel. The resulting panel includes representation from listed and unlisted telephone numbers, telephone and non-telephone households, mobile phone-only households, and households with and without internet access. A random sample of panel members yielded 2279 survey respondents, for a stage completion rate of approximately 34\% [7]. Participants were invited via e-mail. The survey was completed online, in English for most participants; 227 respondents completed it in Spanish. RTI International's Institutional Review Board designated the study protocol as exempt from human subjects approval. All methods were carried out in accordance with relevant guidelines and regulations. Informed consent was obtained from all participants.

\section{Measures}

The survey assessed willingness to receive a vaccine when one becomes available, beliefs about the virus, and demographic characteristics (Table 1).

\section{Analyses}

We report unweighted frequencies and weighted percentages and odds ratios. A post-stratification process was used to adjust for survey nonresponse and any noncoverage, undersampling, or oversampling resulting from the study-specific sample design. The panel provider used data from the U.S. Census Bureau (https://www.census.gov/programs-surveys/cps.html) to weight all respondents to benchmarks for gender, age, race/ethnicity, education level, Census region, household income, metropolitan area, and homeownership status.

Weighted multivariable logistic regression examined predictors of willingness to vaccinate oneself and one's child (dichotomized as willing vs. not willing). Predictor variables were gender, education, race/ethnicity, Hispanic origin, health insurance, income, previous seasonal influenza vaccination, COVID-19 severe disease risk factors (age 65+, BMI > 40, chronic health conditions), perceived threat of the virus, and worry. Critical alpha for statistical significance was set at .05 .

Table 1 Survey measures related to novel coronavirus and potential vaccination

\begin{tabular}{|c|c|c|c|}
\hline $\begin{array}{l}\text { Type of } \\
\text { variable }\end{array}$ & Construct & Question & Response options (and recoding) \\
\hline \multirow[t]{2}{*}{ Outcomes } & $\begin{array}{l}\text { Willingness to } \\
\text { receive the } \\
\text { vaccine }\end{array}$ & $\begin{array}{l}\text { When a vaccine for the Coronavirus } \\
\text { becomes available, I will get it. }\end{array}$ & $\begin{array}{l}\text { Strongly disagree; disagree; agree; strongly agree (recoded as willing or } \\
\text { not willing) }\end{array}$ \\
\hline & $\begin{array}{l}\text { Willingness to } \\
\text { vaccinate the } \\
\text { child }\end{array}$ & $\begin{array}{l}\text { When a vaccine for Coronavirus becomes } \\
\text { available, I will have my child get it. }\end{array}$ & $\begin{array}{l}\text { Strongly disagree; disagree; agree; strongly agree (recoded as } \\
\text { dichotomous) }\end{array}$ \\
\hline \multirow[t]{4}{*}{ Predictors } & $\begin{array}{l}\text { Underlying } \\
\text { medical } \\
\text { conditions }\end{array}$ & $\begin{array}{l}\text { Who in your household has any of the } \\
\text { following: } \\
\text {-Chronic kidney disease (undergoing dialysis) } \\
\text { or liver disease (e.g., cirrhosis, chronic } \\
\text { hepatitis)? } \\
\text {-a compromised immune system } \\
\text { (immunosuppression)? } \\
\text {-diabetes? } \\
\text {-a serious heart condition? } \\
\text {-chronic lung disease? } \\
\text {-moderate to severe asthma? }\end{array}$ & $\begin{array}{l}\text { Myself; someone in my household other than me; no one (for this } \\
\text { measure, we used only respondents' answers about themselves) }\end{array}$ \\
\hline & Worry & I am worried about getting the Coronavirus & Strongly agree; agree; disagree; strongly disagree \\
\hline & Perceived threat & $\begin{array}{l}\text { What level of threat do you think the } \\
\text { Coronavirus poses to each of the following? } \\
\text { you or your family } \\
\text { (Other objects of threat were included on } \\
\text { the survey but will be reported elsewhere.) }\end{array}$ & $\begin{array}{l}\text { Very high threat; high threat; moderate threat; low threat; very low } \\
\text { threat; don't know (Recoded into a four-level item: low/very low; mod- } \\
\text { erate; high/very high; don't know) }\end{array}$ \\
\hline & $\begin{array}{l}\text { Past flu } \\
\text { vaccination } \\
\text { behavior }\end{array}$ & $\begin{array}{l}\text { When was the last time you were vaccinated } \\
\text { for the flu? }\end{array}$ & $\begin{array}{l}\text { Less than } 1 \text { year ago; } 1-2 \text { years ago; } 3 \text { or more years ago; or I have } \\
\text { never been vaccinated for the flu }\end{array}$ \\
\hline
\end{tabular}




\section{Results}

Twenty-two percent of participants were age 65 or older (see Table 2). Seventeen percent had a BMI over 40, and $26 \%$ had one or more underlying medical conditions that could put them at higher risk of severe illness from the virus. Fifty-four percent had received the seasonal influenza vaccine in the last year, while $18 \%$ reported that they had never received the seasonal influenza vaccine. Twenty-seven percent of respondents had children.

Overall, 75\% were willing to get a COVID-19 vaccine when it becomes available (37\% strongly agreed and 38\% agreed). Willingness for their children was similar, at $73 \%$ (32\% strongly agreed and $41 \%$ agreed). Asked about the level of threat from the virus posed to self and family, $8 \%$ answered "very high," 15\% answered "high," 40\% said "moderate," and 33\% said "low or very low." $4 \%$ did not know. Sixty-eight percent reported being worried about getting the novel coronavirus.

\section{Associations with willingness}

Black respondents were less willing to get the vaccine than White respondents ( $53 \%$ vs. $79 \%$, OR $=0.34,95 \%$ $\mathrm{CI}=0.22-0.54$, Table 3 ). Willingness to get vaccinated was also lower among respondents with the lowest annual incomes $(<\$ 50,000 \mathrm{OR}=0.66,95 \% \mathrm{CI}=0.44-1.01$; $\$ 50,000-\$ 99,999$ OR $=0.65,95 \% \mathrm{CI}=0.44-0.97 ; \geq \$ 150$, $000=\mathrm{REF})$ and those without health insurance $(\mathrm{OR}=$ $0.44,95 \% \mathrm{CI}=0.27-0.72$ ). Willingness to get the vaccine for oneself was higher for male than female adults (79\% vs. $72 \%, \mathrm{OR}=1.56,95 \% \mathrm{CI}=1.20-2.03$ ) and lower for those with less education.

As for others in high-risk groups, willingness was higher for those age 65 or older, and Hispanics compared to other respondents (Table 2). However, those with underlying medical conditions and $\mathrm{BMI}>40$ were not more willing to get vaccinated than those without these risk factors.

Willingness to get vaccinated was higher among those who were worried about getting the novel coronavirus (strongly agree $86 \%, \mathrm{OR}=5.37,95 \% \mathrm{CI}=3.10-9.29$; agree $82 \%, \mathrm{OR}=3.96,95 \% \mathrm{CI}=2.51-6.25$; disagree $66 \%$, $\mathrm{OR}=1.82,95 \% \mathrm{CI}=1.14-2.88)$ as compared to those least worried (strongly disagree $=44 \%$ ). Willingness to get vaccinated was higher among those with moderate perceived threat $(80 \%$; OR $=1.42,95 \% \mathrm{CI}=1.04-1.94$ ) and lower among those who answered "don't know" about the threat to themselves or family $(37 \%$; OR $=$ $0.33,95 \% \mathrm{CI}=0.17-0.63)$ than among those with the lowest level of threat (69\%). High perceived threat was not statistically significant.

Willingness to get vaccinated was higher among those who received a seasonal influenza vaccine in the past year than those who had not $(90 \%$ vs. $59 \%$, OR $=4.70$,
95\% CI $=3.55-6.23)$. Willingness to vaccinate children showed a similar pattern of results (Table 3 ).

\section{Discussion}

In a large nationally representative survey conducted in April 2020, the willingness of U.S. adults to receive a novel coronavirus vaccine was high. Most U.S. adults were willing to get the vaccine for themselves and for their children, which is encouraging in a climate in which vaccine hesitancy around childhood immunizations has received global attention. Those most willing to get a COVID-19 vaccine were over age 65 , had a bachelor's degree or higher, were worried about the novel coronavirus, and had received an influenza vaccine in the previous year.

Our estimate of the percentage of people who indicated that they were not willing to get vaccinated is similar to other polls during the same time period (e.g., [8]), but our estimate of those willing to vaccinate was somewhat higher. One explanation is that our survey forced respondents to report willingness or unwillingness to get the vaccine because the item did not include "don't know" or "not sure" response options. Thus, our findings suggest that those who report they are unsure in some polls may be willing to do so when pressed to decide. More research is needed to determine the conditions under which that willingness will translate into action when the time comes to vaccinate.

Studies during previous infectious disease outbreaks suggest somewhat lower willingness to get a new vaccine during a pandemic of a novel pathogen. During the 2009 influenza A (H1N1) pandemic, 64\% of adults in two North Carolina counties intended to receive a vaccine when available [9]. In that study, seasonal influenza vaccination was associated with intentions to get the H1N1 vaccine, but other factors (H1N1 vaccine knowledge, age, gender, race/ethnicity, work status, and having children under age 18 living at home) were not. During the 2016 Zika virus pandemic, 56\% of respondents in a national study were willing to get the hypothetical vaccine [10]. The higher willingness to obtain a COVID-19 vaccine than those for these two previous disease outbreaks may reflect higher media coverage and higher perceived threat of COVID-19.

Black respondents were markedly less willing than White respondents to get a COVID-19 vaccine, a finding that is consistent with adult vaccination trends of, for example, lower seasonal influence vaccine coverage in the same group [11]. Given that Black people have experienced disproportionately high rates of hospitalization and death from COVID-19 [12], the disparity in COVID-19 vaccine willingness raises the possibility that vaccination could amplify existing disparities. Respondents of Hispanic origin expressed higher willingness 
Table 2 Participant characteristics ( $n=2247)$

\begin{tabular}{|c|c|}
\hline Characteristics & $\begin{array}{l}\text { Number of } \\
\text { Individuals }\end{array}$ \\
\hline \multicolumn{2}{|l|}{ Demographics } \\
\hline \multicolumn{2}{|l|}{ Gender } \\
\hline Male & 1158 \\
\hline Female & 1089 \\
\hline \multicolumn{2}{|l|}{ Education } \\
\hline$<$ High school & 190 \\
\hline High school & 578 \\
\hline Some college & 611 \\
\hline Bachelor's degree or higher & 868 \\
\hline \multicolumn{2}{|l|}{ Race/ethnicity } \\
\hline White & 1876 \\
\hline Black & 183 \\
\hline Other & 188 \\
\hline \multicolumn{2}{|l|}{ Hispanic origin } \\
\hline Yes & 441 \\
\hline No & 1806 \\
\hline \multicolumn{2}{|l|}{ Income, annual } \\
\hline$<\$ 25,000$ & 253 \\
\hline$\$ 25,000-\$ 49,999$ & 408 \\
\hline$\$ 50,000-\$ 99,999$ & 729 \\
\hline$\$ 100,000-\$ 149,999$ & 394 \\
\hline$\geq \$ 150,000$ & 463 \\
\hline \multicolumn{2}{|l|}{ Employed } \\
\hline Yes & 1489 \\
\hline No & 758 \\
\hline
\end{tabular}

Health insurance

Employer/union 1044

Medicare/Department of Veterans $\quad 455 \quad 20$

Affairs

Medicaid 132

Other

None

Don't know/refused

Has children age 0-18

Yes

No

132

144

130

342

48

52

11

28

28

34

78

12

10

16

84

13

18

31

16

21

65

35

7

6

6

16

Received seasonal influenza vaccine in past year

Yes

1245

No

Unknown

994

8

\section{Severe COVID-19 risk factors}

Age, years

$$
\begin{array}{r}
18-24 \\
25-34
\end{array}
$$$$
186
$$

Table 2 Participant characteristics ( $n=2247)$ (Continued)

\begin{tabular}{lll}
\hline Characteristics & $\begin{array}{l}\text { Number of } \\
\text { Individuals }\end{array}$ & $\begin{array}{l}\text { Weighted } \\
\%\end{array}$ \\
\hline $35-49$ & 531 & 24 \\
$50-64$ & 668 & 26 \\
$65+$ & 511 & 22 \\
Had a chronic medical condition & & \\
Yes & 584 & 26 \\
No & 1582 & 71 \\
Unknown & 81 & 4 \\
Severe obesity (BMI > 40) & & \\
Yes & 395 & 17 \\
No & 1740 & 78 \\
Unknown & 112 & 5
\end{tabular}

Risk appraisals

Worried about getting the novel coronavirus

$\begin{array}{lll}\text { Strongly agree } & 453 & 20 \\ \text { Agree } & 1070 & 47 \\ \text { Disagree } & 537 & 24 \\ \text { Strongly disagree } & 178 & 8 \\ \text { Unknown } & 9 & 1\end{array}$

Perceived threat from novel coronavirus

High/very high $\quad 512 \quad 24$

Moderate $911 \quad 40$

Low/very low $\quad 738$

Don't know $\quad 82 \quad 4$

$\begin{array}{lll}\text { Refused } & 4 & 0\end{array}$

Note: $B M I$ body mass index, REF reference group

than their non-Hispanic counterparts to get the vaccine. Although adult vaccine coverage has generally been lower for Hispanics than non-Hispanic Whites in recent years [13], their greater willingness to get a COVID-19 vaccine may reflect the virus's disproportionate impact on Hispanic communities (e.g., [14]). It will be imperative to ensure equitable access to the vaccine even as efforts address vaccine hesitancy among diverse communities. The upcoming report by the National Academies of Sciences, Engineering, and Medicine on this question will provide critical guidance for the nation on addressing disparities in vaccine distribution and uptake.

People with lower socioeconomic status were generally less willing to get vaccinated. Lower income and lower education respondents had less willingness to get the vaccine. Those without insurance were nearly 30\% less willing to get the vaccine than insured respondents. Interventions aimed at reducing financial barriers to vaccination and increasing vaccine availability are among the most successful [15]. Equity-oriented policy 
Table 3 Results of logistic regressions for willingness to get vaccine for self and child

\begin{tabular}{|c|c|c|c|c|c|c|}
\hline \multirow[t]{2}{*}{ Variable } & \multicolumn{3}{|c|}{ Willingness for Self } & \multicolumn{3}{|c|}{ Willingness for Child } \\
\hline & $n($ Wtd \%) & Adjusted OR (95\% CI) & $P$ & $n$ (Wtd \%) & Adjusted OR $(95 \% \mathrm{Cl})$ & $p$ \\
\hline \multicolumn{7}{|l|}{ Gender } \\
\hline Male & $932(78.9)$ & $1.56(1.20,2.03)$ & 0.001 & $645(73.5)$ & $1.32(1.01,1.75)$ & 0.045 \\
\hline Female & $805(72.3)$ & REF & & $557(68.1)$ & REF & \\
\hline \multicolumn{7}{|l|}{ Age, years } \\
\hline $18-24$ & $144(75.3)$ & $0.89(0.52,1.50)$ & 0.655 & $98(73.6)$ & $1.00(0.56,1.78)$ & 0.991 \\
\hline $25-34$ & $253(69.7)$ & $0.65(0.41,1.02)$ & 0.063 & $165(62.7)$ & $0.57(0.36,0.90)$ & 0.017 \\
\hline $35-49$ & $387(71.6)$ & $0.52(0.34,0.79)$ & 0.002 & $317(69.2)$ & $0.58(0.38,0.88)$ & 0.010 \\
\hline $50-64$ & $510(74.8)$ & $0.62(0.42,0.92)$ & 0.017 & $348(69.1)$ & $0.63(0.42,0.94)$ & 0.024 \\
\hline $65+$ & $443(84.9)$ & REF & & $274(80.4)$ & REF & \\
\hline \multicolumn{7}{|l|}{ Education } \\
\hline High school or less & $542(68.7)$ & $0.55(0.38,0.79)$ & 0.001 & $382(63.7)$ & $0.54(0.37,0.79)$ & 0.001 \\
\hline Some college & $457(73.5)$ & $0.65(0.47,0.91)$ & 0.011 & $326(70.5)$ & $0.77(0.55,1.09)$ & 0.146 \\
\hline Bachelor's degree or higher & $738(84.8)$ & REF & & $494(79.3)$ & REF & \\
\hline \multicolumn{7}{|l|}{ Race/ethnicity } \\
\hline White & $1498(79.0)$ & REF & & $1024(74.4)$ & REF & \\
\hline Black & $100(53.3)$ & $0.34(0.22,0.54)$ & $<.001$ & $75(48.1)$ & $0.34(0.22,0.52)$ & $<.001$ \\
\hline Other & $139(74.3)$ & $0.65(0.40,1.05)$ & 0.080 & $103(72.3)$ & $0.76(0.45,1.28)$ & 0.296 \\
\hline \multicolumn{7}{|l|}{ Hispanic origin } \\
\hline Yes & $352(80.2)$ & $1.72(1.20,2.46)$ & 0.003 & $301(79.4)$ & $1.89(1.31,2.72)$ & $<.001$ \\
\hline No & $1385(74.5)$ & REF & & $901(68.6)$ & REF & \\
\hline \multicolumn{7}{|l|}{ Income } \\
\hline$<\$ 50,000$ & $466(67.8)$ & $0.66(0.44,1.01)$ & 0.057 & $321(62.0)$ & $0.55(0.35,0.87)$ & 0.011 \\
\hline$\$ 50,000-\$ 99,999$ & $557(74.2)$ & $0.65(0.44,0.97)$ & 0.033 & $380(69.6)$ & $0.66(0.43,1.00)$ & 0.048 \\
\hline$\$ 100,000-\$ 149,999$ & $325(81.4)$ & $0.97(0.61,1.55)$ & 0.912 & $232(78.4)$ & $1.02(0.63,1.65)$ & 0.940 \\
\hline$\geq \$ 150,000$ & $389(84.1)$ & REF & & $269(80.1)$ & REF & \\
\hline \multicolumn{7}{|l|}{ Health insurance } \\
\hline Insured & $1402(77.8)$ & REF & & $947(71.9)$ & REF & \\
\hline Not insured & $69(46.7)$ & $0.44(0.27,0.72)$ & 0.001 & $50(49.0)$ & $0.64(0.37,1.12)$ & 0.118 \\
\hline Don't know/refused & $266(75.5)$ & $1.15(0.78,1.69)$ & 0.490 & $205(73.3)$ & $1.46(1.00,2.15)$ & 0.053 \\
\hline \multicolumn{7}{|l|}{ Received flu vaccine in past year } \\
\hline Yes & $1132(89.5)$ & $4.70(3.55,6.23)$ & $<.001$ & $773(83.3)$ & $3.13(2.37,4.14)$ & $<.001$ \\
\hline No & $601(58.9)$ & REF & & $426(56.0)$ & REF & \\
\hline \multicolumn{7}{|l|}{ Had a chronic medical condition } \\
\hline Yes & $473(79.4)$ & $0.85(0.62,1.15)$ & 0.291 & $315(73.3)$ & $\mathrm{N} / \mathrm{A}$ & \\
\hline No & $1199(73.7)$ & REF & & $845(69.7)$ & & \\
\hline \multicolumn{7}{|l|}{ Severe obesity $(\mathrm{BMI}>40)$} \\
\hline Yes & $311(77.3)$ & $1.09(0.79,1.50)$ & 0.614 & $210(70.8)$ & N/A & \\
\hline No & $1338(75.0)$ & REF & & $932(70.7)$ & & \\
\hline \multicolumn{7}{|c|}{ Worried about getting the coronavirus } \\
\hline Strongly agree & $398(86.2)$ & $5.37(3.10,9.29)$ & $<.001$ & $290(82.3)$ & $5.70(3.21,10.13)$ & $<.001$ \\
\hline Agree & $891(81.9)$ & $3.96(2.51,6.25)$ & $<.001$ & $606(77.1)$ & $4.56(2.76,7.52)$ & $<.001$ \\
\hline Disagree & $365(65.7)$ & $1.82(1.14,2.88)$ & 0.011 & $254(60.4)$ & $2.20(1.35,3.57)$ & 0.002 \\
\hline Strongly disagree & 81 (43.8) & REF & & 50 (38.9) & REF & \\
\hline
\end{tabular}


Table 3 Results of logistic regressions for willingness to get vaccine for self and child (Continued)

\begin{tabular}{|c|c|c|c|c|c|c|}
\hline \multirow[t]{2}{*}{ Variable } & \multicolumn{3}{|c|}{ Willingness for Self } & \multicolumn{3}{|c|}{ Willingness for Child } \\
\hline & $n(\mathrm{Wtd} \%)$ & Adjusted OR (95\% Cl) & $P$ & $n($ Wtd \%) & Adjusted OR $(95 \% \mathrm{Cl})$ & $p$ \\
\hline \multicolumn{7}{|c|}{ Perceived threat from the coronavirus } \\
\hline High/very high & $437(82.3)$ & $1.46(0.99,2.16)$ & 0.054 & $316(80.4)$ & $1.82(1.21,2.72)$ & 0.004 \\
\hline Moderate & $742(80.2)$ & $1.42(1.04,1.94)$ & 0.026 & $504(73.4)$ & $1.21(0.88,1.66)$ & 0.247 \\
\hline Low/very low & $520(68.7)$ & REF & & $349(62.3)$ & REF & \\
\hline Don't know/Refused & $36(37.4)$ & $0.33(0.17,0.63)$ & 0.001 & $30(49.1)$ & $0.80(0.41,1.56)$ & 0.514 \\
\hline
\end{tabular}

Note. Analysis of vaccination willingness for self included 1737 respondents. Analysis of vaccination willingness for child included 1202 respondents. BMI body mass index, OR odds ratio, REF reference group, Wtd weighted

initiatives focused on cost and access barriers will need to be coupled with communication efforts to make sure those who need them are aware of the options available to them.

\section{Implications for health communication}

Our findings have implications for public health communication interventions.

Perceived and actual risk showed different patterns of association in our study. Individuals with higher risk appraisals-perceived threat and greater worry-were more willing to get vaccinated, a finding that is consistent with previous research [16]. However, willingness to get a vaccine was not always associated with being at objectively high risk for severe COVID-19. Individuals over age 65 were more willing than some younger age groups; however, individuals with underlying medical conditions and those with BMI $>40$ were not more willing. Healthcare providers treating individuals with these conditions may have an opportunity to help them better understand their risk.

The public has been inundated with information about COVID-19. The question is no longer whether to communicate, but how to effectively provide accurate information to meet the vaccination needs of U.S. adults. The Extended Parallel Process Model [17] suggests that health messages are more likely to result in health behavior when they are threatening and lead people to believe the recommended behavior is effective at reducing the threat. Messages that emphasize both the significant threat of this virus to people most at risk and the effectiveness of a recommended vaccine (once that is known) could help persuade those who are on the fence about vaccination [18]. That message strategy paired with an audience segmentation approach that addresses those less willing or unsure about vaccination (e.g., those with lower education, those of Black race, and those without insurance) would be a good starting point for health communication campaigns.

\section{Strengths and limitations}

Our study relied on a representative national sample of U.S. adults to quickly gather data on a pressing public health problem. We recognize that we were asking about a hypothetical behavior. Nonetheless, understanding how perceptions are changing can provide helpful information for public health planning and communication. Prior research has shown that behavioral willingness is highly correlated with actual behavior and may even predict behavior independent of intentions [19].

\section{Conclusions}

The findings from this study provide direction about areas to focus public health planning and communication efforts as vaccine efforts continue.

Future research should focus on reasons for some of the differences we found as well as explore how communication about the virus and vaccination has changed perceptions since this survey was conducted in April 2020. These results offer a snapshot of public perceptions early in U.S. COVID-19 pandemic experience. As public perceptions change over time, we can expect communication to continue to play a critical role in generating confidence in the programs and policies that allow nations to achieve high vaccine uptake [15]. Social processes including provider recommendations, social norms, and social media sharing also likely play an important role in vaccine uptake. Our study shows great willingness among Americans to vaccinate and yet we also can see possibilities for notable differences between some groups that warrant efforts to mitigate health inequity.

\footnotetext{
Acknowledgements

NA

Authors' contributions

BJK contributed to conception of the paper; designed the analyses; interpreted the data; developed the first draft and revised the paper. LBS and LAM designed the survey and data collection; and substantively revised the paper. BGS helped conceive of the paper and analyses; interpreted the data and revised the draft. NTB helped to develop the plan for analyses and revised the draft. $C B$ and $A F$ helped with design of the survey and collection of the data and also revised the draft. PDDM helped with design of the
} 
study and data collection and revised the draft. CMB conducted all analyses and revised the draft. The authors read and approved the final manuscript.

\section{Authors' information}

NA

\section{Funding}

NA (No external funding was received).

\section{Availability of data and materials}

The dataset generated during the current study is not publicly available due to the fact that authors are still analyzing data on other survey topics and producing additional reports.

\section{Declarations}

\section{Ethics approval and consent to participate}

Our protocol was reviewed by RTI's Institutional Review Board. All participants provided consent to participate. All methods were carried out in accordance with relevant guidelines and regulations.

\section{Consent for publication}

NA

\section{Competing interests}

NTB has served as a paid advisor for Merck. The remaining authors did not declare conflicts of interest. The other authors declare that they have no competing interests.

\section{Author details}

${ }^{1}$ RTI International, Research Triangle Park, 701 13th St. NW, Ste. 750, Washington, DC 20005, USA. ${ }^{2}$ Gillings School of Global Public Health, University of North Carolina, Chapel Hill, North Carolina, USA.

Received: 11 November 2020 Accepted: 24 March 2021

Published online: 12 April 2021

\section{References}

1. Gottlieb, S., McClellan, M. (21, February 7). What to Do When There's a Covid-19 Vaccine Glut. Supply is ramping up, but many Americans are reluctant to get the shot and need to be persuaded. The Wall Street Journal. https://www.wsj.com/articles/what-to-do-when-theres-a-covid-19-va ccine-glut-11612732696.

2. Rosenbaum L. NEJM (2021). Escaping Catch-22-Overcoming COVID vaccine hesitancy. New Engl J Med 2021; DOI: https://doi.org/10.1056/NEJMms21 01220

3. Lazarus. J.V., Ratzan. S.C., Palayew, A., Gostin L.O., Larson, H.J., Rabin, K, Kimball, S. \& El-Mohandes, A. (2020). A global survey of potential acceptance of a COVID-19 vaccine. Nat Med; Epub ahead of print: 1-4.

4. Rhodes A, Hoq M, Measey M-A, Danchin M. Intention to vaccinate against COVID-19 in Australia. Lancet. 2020:\$1473:30724-6.

5. Harapan H, Wagner AL, Yufika A, Winardi W, Anwar S, Gan AK, et al. Acceptance of a COVID-19 vaccine in southeast Asia: A cross-sectional study in Indonesia. Front Public Health. 2020;8:381

6. Centers for Disease Control and Prevention. People who are at higher risk for severe illness. https://www.cdc.gov/coronavirus/2019-ncov/need-extraprecautions/groups-at-higher-risk.html [accessed 24 June, 2020].

7. Callegaro M, Disogra C. Computing response metrics for online panels. Public Opin Q. 2008;72:1008-32 https://doi.org/10.1093/poq/nfn065.

8. Neergaard L, Fingerhut H. AP-NORC poll: Half of Americans would get a COVID-19 vaccine. 2020. https://apnews.com/dacdc8bc428dd4df6511bfa2 59cfec44 [accessed 24 June 2020].

9. Horney JA, Moore Z, Davis M, MacDonald PDM. Intent to receive pandemic influenza $\mathrm{A}(\mathrm{H} 1 \mathrm{~N} 1)$ vaccine, ability to comply with social distancing and sources of $\mathrm{H} 1 \mathrm{~N} 1$ information in North Carolina communities. PLoS One. 2010;5(6):e11226. https://doi.org/10.1371/journal.pone.0011226.

10. Squiers L, Herrington J, Kelly B, Bann C, Becker-Dreps S, Stamm L, et al. Zika virus prevention: U.S. travelers' knowledge, risk perceptions, and behavioral intentions-a national survey. Am J Trop Med Hyg. 2018;98:1837-47. https:// doi.org/10.4269/ajtmh.17-0898.
11. Williams WW, Lu P-J, O'Halloran AO, Kim DK, Grohskopf LA, Pilishvili T, et al. Surveillance of vaccination coverage among adult populations - United States, 2015. MMWR Surveill Summ. 2017;66:1-28 https://doi.org/10.15585/ mmwr.ss6611a1.

12. Price-Haywood E, Burton J, Fort D, Seoane L. Hospitalization and mortality among black patients and white patients with COVID-19. N Engl J Med 2020, epub ahead of print. doi: https://doi.org/10.1056/NEJMsa2011686

13. Lu P-I, O'Halloran A, Williams WW, Lindley M, Farrall S, Bridges CB. Racial and ethnic disparities in vaccination coverage among adult populations. Am J Prev Med. 2014:S412-25.

14. Lardieri A. (2020). Hispanics and Blacks are hardest hit by COVID-19 in New York City. U.S. News. https://www.usnews.com/news/national-news/a rticles/2020-04-08/coronavirus-disproportionally-kills-hispanics-and-blacks-innew-york-city [accessed 24 June 2020]

15. Brewer NT, Chapman GB, Rothman AJ, Leask J, Kempe A. Increasing vaccination: Putting psychological science into action. Psychol Sci Pub Interest. 2017:18:149-207. https://doi.org/10.1177/1529100618760521.

16. Brewer NT, Chapman GB, Gibbons FX, Gerrard M, McCaul KD, Weinstein ND. Meta-analysis of the relationship between risk perception and health behavior: the example of vaccination. Health Psychol. 2007;26:136. https:// doi.org/10.1037/0278-6133.26.2.136.

17. Witte K. Putting the fear back into fear appeals. The extended parallel process model. Commun Monographs 1992. 1992:59:329-49 https://doi. org/10.1080/03637759209376276.

18. Tannenbaum MB, Hepler J, Zimmerman RS, Saul L, Jacobs S, Wilson K, et al. Appealing to fear: a meta-analysis of fear appeal effectiveness and theories. Psycholog Bull. 2015;141:1178 https://doi.org/10.1037/a0039729.

19. Gibbons FX, Gerrard M, Ouellette JA, Burzette R. Cognitive antecedents to adolescent health risk: Discriminating between behavioral intention and behavioral willingness. Psychol Health. 2007;13:319-39 https://doi.org/10.1 080/08870449808406754.

\section{Publisher's Note}

Springer Nature remains neutral with regard to jurisdictional claims in published maps and institutional affiliations.

\section{Ready to submit your research? Choose BMC and benefit from:}

- fast, convenient online submission

- thorough peer review by experienced researchers in your field

- rapid publication on acceptance

- support for research data, including large and complex data types

- gold Open Access which fosters wider collaboration and increased citations

- maximum visibility for your research: over $100 \mathrm{M}$ website views per year

At $\mathrm{BMC}$, research is always in progress.

Learn more biomedcentral.com/submissions 